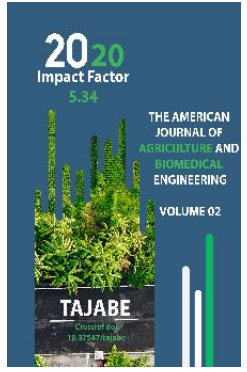

\title{
Effectiveness Of New Preparative Forms Of Sulfur Against Spider Mite On Cotton
}

\author{
Baltaev Botir Safarovich \\ Candidate Of Agricultural Sciences, Associate Professor, Tashkent State Agrarian University, \\ Tashkent, Uzbekistan.
}

\footnotetext{
Journal Website: http://usajournalshub.c om/index,php/tajabe

Copyright: Original content from this work may be used under the terms of the creative commons attributes 4.0 licence.
}

\section{ABSTRACT}

The article summarizes the results of the use of new preparative forms of sulfur against spider mites on cotton. As surfactants, water-soluble polymers, conventional synthetic detergents and soap stock (waste oil-fat factories production after processing cotton seeds) are used. The data of the author of the development of methods for the use of drugs against the most important pests of agricultural crops are presented The question of ways to increase the efficiency of sulfur preparations is discussed.

\section{KEYWORDS}

Cotton plant, spider mite, sulfur, acaricide, efficiency, surfactant, surfactants, stabilized, entomophages, pests, sucking, stimulation, integrated, program, polymers, waste production.

\section{INTRODUCTION}

Among the numerous pests of cotton (cotton, small terrestrial (caradrina), winter moth, aphids, tobacco thrips, etc.), the spider mite was and remains a dangerous pest. In the absence of a fight against it, the loss of raw cotton yield reaches up to $60 \%$. In the integrated system of plant protection, a large place is given to the biological method, however, on cotton against spider mites, various chemical agents have to be used, which often adversely affect the beneficial entomofauna and, in addition, cause the emergence of resistant populations. From this point of view, the use of sulfur preparations in the integrated protection of cotton against 
pests, in particular from spider mites, is gaining in importance.

However, sulfur preparations existing for the control of pests of cotton and other agricultural crops - ground sulfur, $80 \%$ of the d.p. sulfur, colloidal sulfur - have certain drawbacks. Sulfur powder during the pollination of plants for a large part is not retained on the leaves, which leads to a multiple increase in consumption rates ... ISO (lime-sulfur broth) requires a lot of labor and money for preparation. All of the listed forms of sulfuric preparations have a short duration. Accounting for the above, the Department of Plant Protection, together with the Institute of Bioorganic Chemistry of the Academy of Sciences of Uzbekistan and the Departments of Synthetic Polymers, Colloidal Chemistry of the Tashkent State University, developed various forms of water-stabilized and waterwettable sulfur (WSS). Our studies were devoted to the study of the toxicological properties of these drugs and the potential for increasing the effectiveness of the fight against spider mites on cotton.

\section{MATERIAL AND RESEARCH TECHNIQUE}

Field and production experiments were carried out in the Syrdarya stationary site, Sardoba region and Tashkent (Sredne-Chirchik region) regions in 1980-2016. The study took into account the meteorological conditions of these areas, as well as the mechanical composition and agrochemical properties of the soils of the experimental plots. In the components VSS-1 (water-wettable sulfur), synthetic detergents (CMC) and water in a weight ratio of 55:40. According to the Uzbek Research Institute of Sanitation, Hygiene and Occupational Disease, VSS-L is a low-toxic agent for warm-blooded animals (Danilov, 1978). The drug was developed by the
Department of Plant Protection, Tashkent State Agrarian University.

VSS-2 - 25\% (in terms of sulfur) stabilized suspension. The components of the preparation are sulfur, water-soluble polymer $\mathrm{k}-10$ and water in a ratio of 25: 1.5: 73.5. BCC-2 was developed by the Department of Colloidal Chemistry of the Tashkent State University. According to the Department of Pharmacology of Disease of the Problem Laboratory of the Chemistry of Natural Compounds of the Tashkent State University, BCC-2 belongs to low-toxic agents.

VSS-3 differs from VSS-2 in that it contains a water-soluble polymer - hydrochloride polydimethylamino ethyl methacrylate (SP-80) as a surfactant. The drug was created at the Department of Chemistry of Synthetic Polymers of Tashkent State University. According to the data of the Department of Pharmacology of the Disease of the Problem Laboratory of the Chemistry of Natural Compounds of the Tashkent State University VSS-3 is malotoxic for warm-blooded animals.

SPV-1 is distinguished by the fact that it uses waste products from processing cotton seeds (coapustok) as a surfactant in oil and fat factories. In addition to acaricidal, growth also has a stimulating effect.

The drug was created at the Institute of Bioorganic Chemistry of the Academy of Sciences of Uzbekistan. As the main object, we selected the spider mite (Tetranychus urticae Koch), additionally - aphids (family Aphididae), tobacco thrips (family Tpripidae), as well as their entomo-acariphages. To study the timing of the appearance and seasonal dynamics of the number of spider mites, tobacco thrips and entomo - acariphages on weeds around fields and on cotton crops, the counts were carried out according to the 
SANIIZR methodology (Uspensky 1979, 1980). The number of spider mites and insects was counted every 5 days, from the moment of emergence to harvest.

To identify the effectiveness of drugs on cotton and weeds, the number of pests and predators was taken into account before treatment and every 5 days after it for 15.30 or more days (Gar, 1963; Uspensky, 1973). Spraying of preparations was carried out using tractor sprayers OBX-14 OBX-28.

Each variant of the experiment was imposed on an area of 1-1.5 hectares in 3 repetitions. During production tests, the area of the variants was 50-100 ha. The toxicity of drugs in the fight against sucking pests of cotton was determined by the Abbot formula.

Mathematical processing of the research results was carried out according to B.A. Dospekhov (1979-1985).

\section{RESULTS AND DISCUSSION}

The research results showed that the spider mite in the conditions of the Syrdarya region, even on newly developed lands, where the maps are enlarged to 50-100 hectares, mulberry plantations are grouped in separate areas, ditches are replaced by concrete trays, etc., is one of the most dangerous cotton pests.

The years of the outbreak of mass reproduction of the tick were characterized by relatively dry and warm spring-summer weather (the hydrothermal coefficient in April-August is 0.34-0.57). Depression of its development is associated with more rainy, cool spring-summer weather (GTK-1.17).

On the newly developed lands, a wave of a shaped fluctuation in the number of spider mites was not observed either on weeds or on cotton, as previously noted by other researchers (Uspensky, 1960, 1970) in the oldirrigated cotton-growing zone. In the spring, they develop mainly on such dicotyledonous weeds as shepherd's purse, yaruk, mallow, field bindweed, etc. growing along the roads.

The number of spider mites on weeds increased from mid-March to autumn (221833440 individuals per $1 \mathrm{m2}$ ), and on cotton from the moment of emergence (1 decade of May) to mid-August (23441-36841 individuals per 100 leaves).

It is characteristic that the density of the spider mite population in the work area almost annually reached the threshold number on weeds in the second and third decades of April, and on cotton in the second decade of June.

A similar pattern is observed in the development of other sucking pests on weeds. On cotton, the mass development of aphids (acacia and cotton) is observed from the second and third decades of May. The maximum number of cotton and alfalfa aphids was recorded on weeds (283-3445 individuals per $1 \mathrm{~m} \mathrm{2}$ ) at the end of May and in the first ten days of June. Then their number gradually decreased.

Entomo-acariphages (lacewings, aphids, tickeating orius thrips and otetorus) appear on weeds from the second and third decades of May, then their number increases depending on the number of the pest and reaches a maximum on cotton (up to 450-611 individuals per 100 plants) and weeds around fields (157 individuals per $1 \mathrm{~m} \mathrm{2}$ ) in the second half of August.

The number of entomo-acariphages mainly depends on the availability of food. In terms of numbers, the first and second places are 
occupied by tick-eating thrips, lacewing, lastaphid cows, and rarely sirphid flies and aphidibians.

Aphids (acacia, cotton and large cotton) and tobacco thrips, like spider mites, initially concentrate on weeds around cotton fields, then gradually move to its crops. The same pattern is observed in the development of the main entomo-acariphages.

It follows from the foregoing that the fight against spider mites and other cotton pests should be organized taking into account their number and the ratio of the main phyto and zoophages. This will allow you to achieve high efficiency in pest control and maximize the preservation of their natural enemies. We chose the spider mite as the main object, additionally aphids and tobacco thrips, as well as their entomo-acariphages.

BCC preparations were used in 1-, 2-3\% (by sulfur) concentration with a working suspension consumption of 300-400 and $600 \mathrm{I}$ / ha. The cotton plant infested with mites was treated with tractor sprayers at different periods of its development. Before processing in the case of odbutonization and flowering, where there were 38.4 to 640 ticks per 100 leaves during the period of fruit formation 3019-3984 about themselves.

We found that $B C C$ preparations have high acaricidal and stimulating (SPV-1) effects on the plant. Treatment with BCC preparations in $2-3 \%$ concentration with a sulfur consumption of 6-12 kg / ha provides a sufficiently high efficiency against spider mites (93.3-98.1\%).

In the years of a high number of ticks, as well as later phases of cotton development, on highly infested fields, the greatest effect was obtained where WSS was used with a consumption (for sulfur) of $16-18 \mathrm{~kg} / \mathrm{ha}$ and a working suspension of $600 \mathrm{l} /$ ha (Table 1 ).

The biological effectiveness against spider mites when treated with BCC-1 was 97.0-98.4; VSS-2-96.0-98.1 ISPV-1- 97.2-98.6\%. The plants remained free of ticks for 20 days, which made it possible to reduce the frequency of treatments with other insect-acaricides. Plants restored their previous appearance, the number of fruit-organs and the mass of raw cotton increased. Under similar conditions, the reference preparations showed a lower biological efficiency: $80 \%$ sulfur concentration$82.6-91.4 \%$, 40\% c.e. $\mathrm{BI}-58-58.1-88.4 \%$.

The results of our studies indicate that after the use of BCC and SPV-80 preparations, the number of lacewings, aphid bugs, tick-eating thrips, orius bugs and stethorans on cotton decreased only within 11-25\%, and in the variant with $\mathrm{Bl}-58$ ( reference) by $90.3 \%$. Economic and biological - economic indicators of efficiency The low toxicity of preparations of water-wetted and water-stabilized sulfur for animals and humans gives a good reason to include in the system of integrated pest control of cotton.

\section{Table 1}

Biological effectiveness of WSS in the fight against spider mites on cotton in the conditions of the Syrdarya region, Sardoba district

1980-2016 
The American Journal of Agriculture And Boimedical Engineering (ISSN - 2689-1018)

Published: August 30, 2020 | Pages: 107-113

Doi: https://doi.org/10.37547/tajabe/Volume02Issueo8-12

\begin{tabular}{|c|c|c|c|c|c|}
\hline \multirow{2}{*}{ Option } & \multirow{2}{*}{$\begin{array}{l}\text { Consumptio } \\
\mathrm{n} \text { rate of the } \\
\text { drug } \mathrm{kg} / \mathrm{ha}\end{array}$} & \multirow{2}{*}{$\begin{array}{c}\text { Number of } \\
\text { mites per } 100 \\
\text { leaves before } \\
\text { treatment, ind. }\end{array}$} & \multicolumn{3}{|c|}{ Biological efficiency, $\%$ per day } \\
\hline & & & 5 th & 10th & 15 th \\
\hline \multirow{4}{*}{ VSS-1 } & 9 & 712 & 97,4 & 98,6 & 90,9 \\
\hline & 12 & 2567 & 94,0 & 91,8 & 88,8 \\
\hline & 16 & 2669 & 98,5 & 97,9 & 97,8 \\
\hline & 18 & 2246 & 98,4 & 98,1 & 97,6 \\
\hline \multirow{3}{*}{ VSS-2 } & 12 & 2989 & 92,8 & 91,1 & 88,4 \\
\hline & 16 & 3179 & 97,3 & 96,8 & 95,7 \\
\hline & 18 & 3077 & 96,4 & 96,5 & 95,4 \\
\hline \multirow{3}{*}{ VSS-3 } & 12 & 1899 & 90,3 & 89,9 & 84,3 \\
\hline & 16 & 1947 & 94,5 & 92,7 & 90,6 \\
\hline & 18 & 2026 & 93,8 & 92,8 & 90,2 \\
\hline \multirow{3}{*}{ SPV-1 } & 9 & 2130 & 94,4 & 97,0 & 92,0 \\
\hline & 12 & 1987 & 97,4 & 98,1 & 97,1 \\
\hline & 18 & 2140 & 98,6 & 98,4 & 97,3 \\
\hline $\begin{array}{l}\text { 80\% d.p. sulfur } \\
\text { (reference) }\end{array}$ & 16 & 2417 & 90,5 & 89,7 & 83,6 \\
\hline $\begin{array}{c}40 \% \text { e. BI-58 } \\
\text { (standard) }\end{array}$ & 2,5 & 2053 & 83,5 & 78,2 & 72,9 \\
\hline \multicolumn{2}{|c|}{$\begin{array}{c}\text { Control } \\
\text { (water treatment) }\end{array}$} & 2565 & 3222 & 4816 & 5672 \\
\hline \multicolumn{3}{|c|}{ NSR 0.5} & 2,76 & 2,92 & 3,09 \\
\hline
\end{tabular}


Intermediate weeds and mulberries around cotton fields are the main reserves of sucking pests, including spider mites. Therefore, carrying out prophylactic and prophylactic measures, which include treatment with $B C C$ preparations, ensures the destruction of pests and preserves beneficial insects.

In the farms of the Syrdarya region, the effectiveness of WSS in the fight against spider mites on weeds was studied. The treatments were carried out with a tractor sprayer. The number of mites on weeds before treatment ranged from 43.6 to 109 individuals per $1 \mathrm{~m} 2$.

It was found that as a result of treatment with BCC - 1, 94.1 - 99.0\% of spider mites died on weeds and the number of aphids partially decreased. The best efficiency was observed in variants where the $\mathrm{BCC}-1$ preparation was used in $2-3 \%$ concentration with a sulfur consumption of $20 \mathrm{~kg} \mathrm{/} \mathrm{ha.} \mathrm{After} \mathrm{such}$ treatment, the weeds remained free of spider mites for about a month.

The value of preventive treatments of weeds in combination with edge treatments of cotton was studied in the conditions of the Syrdarya and Tashkent regions. A significant decrease in the number of ticks after preventive treatment of weeds and cotton with WSS preparations was noted, the frequency of subsequent extermination treatments was reduced. So, when spraying BCC - 1 weeds around fields as a 20 meter marginal strip, the number of mites on cotton plants decreased by 2 times, while when treating with a $2 \%$ suspension of $B C C$ - 1 weeds around fields during the period of mass emergence of cotton seedlings, as well as a 20 - meter strip of crops during the period budding - more than 3 times. In this case, the need for special destructive processing of cotton appeared only by mid-July. The same high efficiency was noted in experiments with double edge processing of cotton with VSS.

In the areas of marginal, focal and selective application of the drug, the total number of entomo - acariphages increased almost twofold. This contributed to an increase in the number of especially sirphids and aphid ladybirds.

The massive development of spider mites and other pests (aphids and scoops) was observed in areas of annual continuous use of insectoacaricides (especially phosphorus and other organic).

To preserve entomo-acariphages before budding, it is advisable to carry out edge treatments of cotton crops with sulfur preparations.

The techniques and tactics we recommend for the use of new forms of sulfur preparations during 2004 - 2017. was introduced in the areas of mass development of spiderweb mites in cotton-growing farms of the Syrdarya and Tashkent regions. The maximum preservation of entomo-acariphages during chemical treatments was ensured, as well as to reduce environmental pollution.

\section{REFERENCES}

1. Khamraev A.Sh., Vanyants G., Boltaev B.S. Water-wettable sulfur. Plant protection 1982. I. - p. 58.

2. Khamraev A.Sh., Boltaev B.S. Waterwettable sulfur against spider mites. // Cotton growing.-1982.-№3.-p. 29.

3. Khamraev A.Sh., Boltaev B.S. The role of weedy environments of cotton fields in the saturation of agrobiocenosis with entomophages of agricultural pests. Weed plants of Uzbekistan and control measures. Scientific. Proceedings of 
TashSKhl. Issue 100.- Tashkent. 1982 .-- p. 68-80.

4. Khamraev A.Sh., Alimov E., Boltaev B.S. An important element of integrated protection. Cotton growing. 1984. No. 7. p. 29-30.

5. Boltaev B.S. The main acari-aphidophages of cotton pests in the conditions of the Hungry Steppe. Integrated protection of cotton from pests and diseases. Sci. Proceedings of TashSKhl. Issue 106. Tashkent, 1983. - p. 40-50.

6. Boltaev B.S. New forms of sulfur preparations in production. The role of chemistry in agriculture Tashkent regional board of VEO im. Mendeleev Abstracts of reports October 29-30, 1985 Tashkent, 1985. - p. 33-35.

7. Boltaev B.S. Bioecological features of spider mites affecting cotton in Golodnaya Steppe and their use in the development of measures to combat it. Protection of plants from pests, diseases and weeds. - Sci. Proceedings of the Tashkent Agricultural Institute, issue, II3. Tashkent, 1985 .-- p. 23-29.

8. Boltaev B.S. Optimization of spider mite control in cotton. Abstracts of the scientific-practical conference "Intensification of agricultural production". - Tashkent regional administration of NTO of agriculture. Tashkent, 1986 .-- p. 65-66.

9. Boltaev B.S. Experience in the conservation and use of natural entomoacariphages. UzNIITI.- No. 463/87. Tashkent, 1987. p. 3.

10. Boltaev B.S. Improvement of the spider mite control system in cotton. Protection of cotton and other crops from pests and diseases. - Scientific. Proceedings of TashSKhl. - Tashkent, 1987 .-- p. 29-32.
11. Boltaev B.S. Efficiency of new sulfur formulations against spider mites on cotton. Abstract of dissertation for the degree of candidate of agricultural sciences. Moscow, 1988, p. 18.

12. Novozhilov K.V., Shapiro V.A. Ways of preserving entomophages during chemical treatments. Biological plant protection products. Moscow "Kolos" 1974. p.21-34.

13. J.A. Matthews. Pest control of agricultural crops. Translation from English. Moscow V.O "Agropromizdat" 1987. p. 89-114.

14. Boltaev B.S., Akhanov D.D., Orynbekova D.U. The best ways to protect cotton from pests. "Innovative projects are the key to the formation of professional competence of specialists." Materials of the scientific conference. Republic of Kazakhstan December 14, 2016, pp. 355359.

15. Integrated plant protection against major pests and diseases in Eastern Europe and the Caucasus. Food and Agriculture Organization of the United Nations. Budapest, 2017.p.10-52. 